\title{
Prevalence and level of Salmonella spp. Contamination on selected pathways of preparation and cooking of fried chicken at the household level
}

\author{
Teti ROSNIAWATI ${ }^{1,2}$, Winiati Pudji RAHAYU ${ }^{3,4 * ~(D), ~ H a r s i ~ D e w a n t a r i ~ K U S U M A N I N G R U M ~}{ }^{3,4}$, \\ Nugroho INDROTRISTANTO ${ }^{2}$, Eva NIKASTRI ${ }^{2}$
}

\begin{abstract}
Homemade foods have been reported as an important contributor to some foodborne outbreaks. This study determined the prevalence and number of Salmonella spp. on selected pathways of fried chicken preparation and cooking at the household level and investigated their antimicrobial resistance. Salmonella serovar was confirmed by polymerase chain reaction (PCR) and partial sequencing using primer 785F and 907R. Samples consisted of chicken meat (raw, pre-cooked and fried), seasoning, water, mortar, and the hands of the food handler. The results showed that Salmonella spp. was found in $22.1 \%$ of 104 samples. The level of Salmonella found was in the range of $0.3 \mathrm{MPN} / \mathrm{g}$ (in fried chicken and water) to $920 \mathrm{MPN} / \mathrm{g}$ (in marinated raw chicken). Six Salmonella serovars were identified, namely S. Typhimurium, S. Bergen, S. Enteritidis strain FORC_052, S. Enteritidis strain GD1011, S. Typhi strain 541, and S. Typhi strain 3N4. Three were resistant to nalidixic acid, while one was resistant to streptomycin.
\end{abstract}

Keywords: antimicrobial resistance; fried chicken; household; Salmonella.

Practical Application: Salmonella spp. prevalence in fried chicken and its antimicrobial resistance properties.

\section{Introduction}

Salmonellosis due to Salmonella spp. in poultry has been reported in America, Asia, and Europe (Kovačić et al., 2017). Fifty-five percent of chicken carcass samples $(\mathrm{n}=40)$ from seven traditional markets and eight supermarkets in Bogor were contaminated by Salmonella spp. (Sylviana \& Kusumaningrum, 2008). The prevalence of Salmonella spp. has also been reported to be $46.6 \%(n=87)$ in chicken meat samples collected from ten cities in Indonesia (Syarifah \& Novarieta, 2015). In addition, the presence of Salmonella spp. in fried chicken has also been found to be $42.0 \%$ of 106 fried chicken samples in Jakarta, with the level between 0.36 and $2.30 \mathrm{MPN} / \mathrm{g}$ (Indonesia National Agency of Drug and Food Control, 2016).

A study conducted by Rosniawati et al. (2018) in 2018 showed that $32.5 \%$ of a sample of 40 housewives had a low understanding of how to implement safety practices in handling chicken carcasses. Therefore, chicken processing practices at the household level need to be improved in order to control the contamination of Salmonella spp. in the finished product. Fried chicken is a favorite side dish in South East Asian countries, including Indonesia. One of the common ways to cook chicken is to fry without flour (unbreaded) using seasoning, with or without a pre-cooking process. The precooking process means that chicken meat is cooked by boiling prior to frying. This study aimed to determine the prevalence and the number of Salmonella spp. on preparation and cooking of fried chicken, and to identify the isolated serovars and their antimicrobial resistance/susceptibility.

\section{Materials and methods}

\subsection{Materials}

10 household's food processor in Jakarta were selected to be the respondents in this study. The preparation of unbreaded fried chicken in households may vary. However, it commonly consists of five steps, starting from receiving raw materials (chicken, water, seasonings), cleaning raw chicken, preparing seasonings, boiling/ marinating, and frying. 104 samples were collected, composed of raw chicken meat (18 samples), seasonings (14 samples), water (20 samples), marinated raw chicken meat (2 samples), pre-cooked chicken meat (16 samples), pre-cooked chicken meat stored for 3 hours at room temperature (4 samples), fried chicken (20 samples), the hand swabs of food handlers ( 7 samples), and the swabs of mortars ( 3 samples). The pre-cooked process was conducted by heating the chicken meat with seasoning (salt, onion, ginger, turmeric and galangal) until the meat is boiled, with a total heating time of approximately 19 to 46 minutes.

\subsection{Sample preparation}

All samples, except water, swabs of food handlers and mortars, were taken with the same weight at a different spot to collect approximately $200 \mathrm{~g}$ and put into containers aseptically. For water, samples were collected from the tap, well, and refilled drinking water (originating from depots). The hands of food handlers and mortars were swabbed prior to preparing fried chicken. 


\section{Sample analysis}

\subsection{Salmonella isolation by the most probable number method}

Salmonella spp. was isolated using the MPN method (Indonesia National Agency of Drug and Food Control, 2016). Food samples (25 g), except water, swabs from food handlers and mortars, were put in sterilized stomacher bags aseptically, and subsequently homogenized in $225 \mathrm{~mL}$ of Buffered Peptone Water (BPW, Oxoid). All samples were diluted serially to $10^{-1}$ and $10^{-2}$. All tubes were incubated at $37^{\circ} \mathrm{C}$ for $24 \mathrm{~h}$.

After incubation, $100 \mu \mathrm{L}$ of each sample was inoculated into selective enrichment Modified Semi-Solid Rappaport Vassiliadis (MSRV, Oxoid), then incubated at $42{ }^{\circ} \mathrm{C}$ for $24 \mathrm{~h}$ to $48 \mathrm{~h}$. The growth of Salmonella spp. was indicated by the presence of white zones in the MSRV medium. The white zone area was streaked on the selective medium Xylose Lysine Deoxycholate Agar (XLDA, Oxoid) and incubated at $37^{\circ} \mathrm{C}$ for $24 \mathrm{~h}$.

A loop from a specific colony (pink colored colony with or without black circles) and a nonspecific colony were streaked on Brain Heart Infusion Agar (BHIA, Oxoid) medium, then incubated at $37{ }^{\circ} \mathrm{C}$ for $24 \mathrm{~h}$. Two loops of isolates from BHIA were transferred into $50 \mu \mathrm{L} \mathrm{NaCl}$ and subsequently homogenized.

\subsection{Salmonella confirmation by the polymerase chain reaction technique}

Salmonella spp. was detected using an optimized PCR technique (Indonesia National Agency of Drug and Food Control, 2016). The positive control bacterium was Salmonella Typhimurium ATCC 14028 while the negative control bacterium was E. coli ATCC 25922. Bacterial sample suspension was extracted to collect DNA using the boiling technique at $100^{\circ} \mathrm{C}$ for $15 \mathrm{~min}$. The boiled tube was treated with a cold shock at $-20^{\circ} \mathrm{C}$ for $2 \mathrm{~min}$, then centrifuged (Hettich, Germany) at $12.000 \mathrm{rpm}$ for $5 \mathrm{~min}$. The supernatant was taken using a pipette and transferred into sterilized $500 \mu \mathrm{L}$ microcentrifuge tubes. The obtained supernatant was used as a DNA template and the absorbance was measured using NanoDrop spectrophotometry (BioDrop, US) at wavelengths of 260 and $280 \mathrm{~nm}$ for the determination of the DNA concentration $(\mathrm{ng} / \mu \mathrm{L})$ and purity level (absorbance ratio of $260 \mathrm{~nm} / 280 \mathrm{~nm}$ ).

DNA was then amplified using the PCR technique. The master mix for PCR reactions was made to $25 \mu \mathrm{L}$ by using a Kit Go Taq Green Master Mix (Promega, USA), consisting of $2.5 \mu \mathrm{L}$ template DNA, $0.5 \mu \mathrm{L}$ Forward and Reverse Primers, $12.5 \mu \mathrm{L}$ Master Mix Go Taq Green, and $9 \mu \mathrm{L}$ Nuclease Free Water. To detect invA genes of Salmonella spp. a specific primer was used, i.e. Forward SalinvA 139 primer (primer sequence (5'-3'): GTG-AAA-TTA-TCG-GCACGT-TCG-GGC-AA) and Reverse SalinvA 141 primer (primer sequence (5'-3'): TCA-TCG-CAC-CGT-CAA-AGG-AAC-C). Target/template DNA (DNA samples, positive control bacterial DNA of S. Typhimurium ATCC 1402 and negative control bacterial DNA of E. coli ATCC 25922) were amplified by PCR (Turbo Cycler, Biometra) as follows: pre-denaturation at $95^{\circ} \mathrm{C}$ for $1 \mathrm{~min}$; denaturation at $95^{\circ} \mathrm{C}$ for $30 \mathrm{~s}$; annealing at $60^{\circ} \mathrm{C}$ for $30 \mathrm{~s}$; elongation at $72{ }^{\circ} \mathrm{C}$ for $30 \mathrm{~s}$; and final extension at $72{ }^{\circ} \mathrm{C}$ for $4 \mathrm{~min}$. The PCR cycle was performed 35 times. Amplification of bacterial DNA was detected using 2\% agarose solution for 45-60 min, depending on the distance of agarose. The electrophoresis (Biometra, Germany) occurred from the negative pole to the positive pole at 75 voltages. The electrophoresis process was stopped after the yellow color almost reached the lower limit. The presence of DNA bands was observed in the position of 284 base pairs and documented by using GelDoc (Biorad, USA).

\subsection{Salmonella serovar analysis by sequencing}

DNA of Salmonella spp. was extracted and amplified using 27F (5’ (AGA GTT TGA TCM TGG CTC AG) 3') and 1492R (5' (TAC GGY TAC CTT GTT ACG ACT T) 3') primers. Amplicon was sequenced using 785F (5' (GGA TTA GAT ACC CTG GTA) 3') and 907R (5' (CCG TCA ATT CMT TTR AGT TT) 3') primer, ABI PRISM 3730 XL Analyzer (96 capillary type) sequencer and Big Dye Terminator v3.1 Cycle Sequencing Kit (Applied Biosystems). The result of sequencing was analyzed and base sequence obtained, then submitted to the Blast process at the NCBI (National Center for Biotechnology Information, 2017) database.

\subsection{Antibiotic resistance testing}

Salmonella spp. isolates obtained from fried chicken processing chains were tested for their resistance according to the Clinical Laboratory Standards Institute using the disk diffusion technique (Clinical \& Laboratory Standards Institute, 2013). Five antibiotics were tested, namely ampicillin $(10 \mu \mathrm{g})$, streptomycin $(10 \mu \mathrm{g})$, tetracycline $(30 \mu \mathrm{g})$, nalidixic acid $(30 \mu \mathrm{g})$, and trimethoprimsulfamethoxazole $(25 \mu \mathrm{g})$. The bacterial isolates were grouped as susceptible (S), intermediate (I), and resistant (R) (Clinical \& Laboratory Standards Institute, 2013).

\section{Results and discussion}

\subsection{Results}

A total of 23 of 104 samples (22.1\%) were contaminated by Salmonella spp. confirmed by PCR. Samples containing Salmonella spp. were indicated by the formation of bands in agarose gel at 284 bp (Figure 1). The highest prevalence of Salmonella spp. was found in raw chicken meat (50.0\%, 9 of 18 samples) in comparison with other samples (Figure 2). PCR step: pre-denaturation at $95^{\circ} \mathrm{C}$ for $1 \mathrm{~min}$; denaturation at $95^{\circ} \mathrm{C}$ for $30 \mathrm{~s}$; annealing at $60{ }^{\circ} \mathrm{C}$ for $30 \mathrm{~s}$; elongation at $72{ }^{\circ} \mathrm{C}$ for $30 \mathrm{~s}$; and final extension at $72{ }^{\circ} \mathrm{C}$ for $4 \mathrm{~min}$. The PCR cycle was carried out 35 times. Salmonella positive samples were shown by a DNA band on 284 bp by gel electrophoresis

Salmonella spp. was also confirmed in pre-cooked chicken meat ( 1 of 16 samples) and fried chicken ( 1 of 20 samples). There was no Salmonella spp. detected in the prepared seasoning samples from the market and tap water. Tables 1 and 2 suggest that the number of Salmonella spp. in raw chicken meat increased after marinating, reaching $920 \mathrm{MPN} / \mathrm{g}$. Further processing, boiling and frying, reduced the number, although two samples (1 of 16 pre-cooked samples; and 1 of 20 fried chicken samples) still contained Salmonella spp. of 0.4 and $0.3 \mathrm{MPN} / \mathrm{g}$, respectively. Three of seven food handler's hands were contaminated by Salmonella spp.: two of them did not wash their hands whereas one of them washed their hands only using well water. 


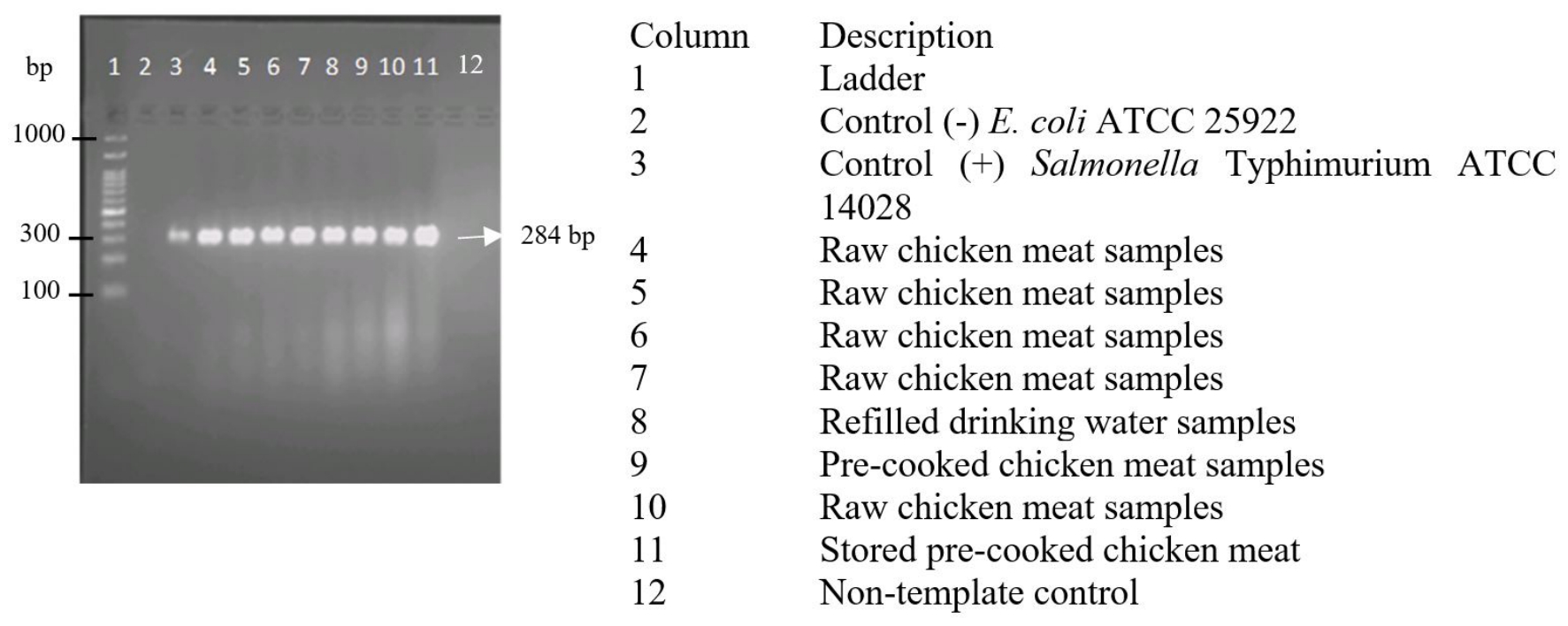

Figure 1. Detection of Salmonella spp. using the PCR technique from different isolates.

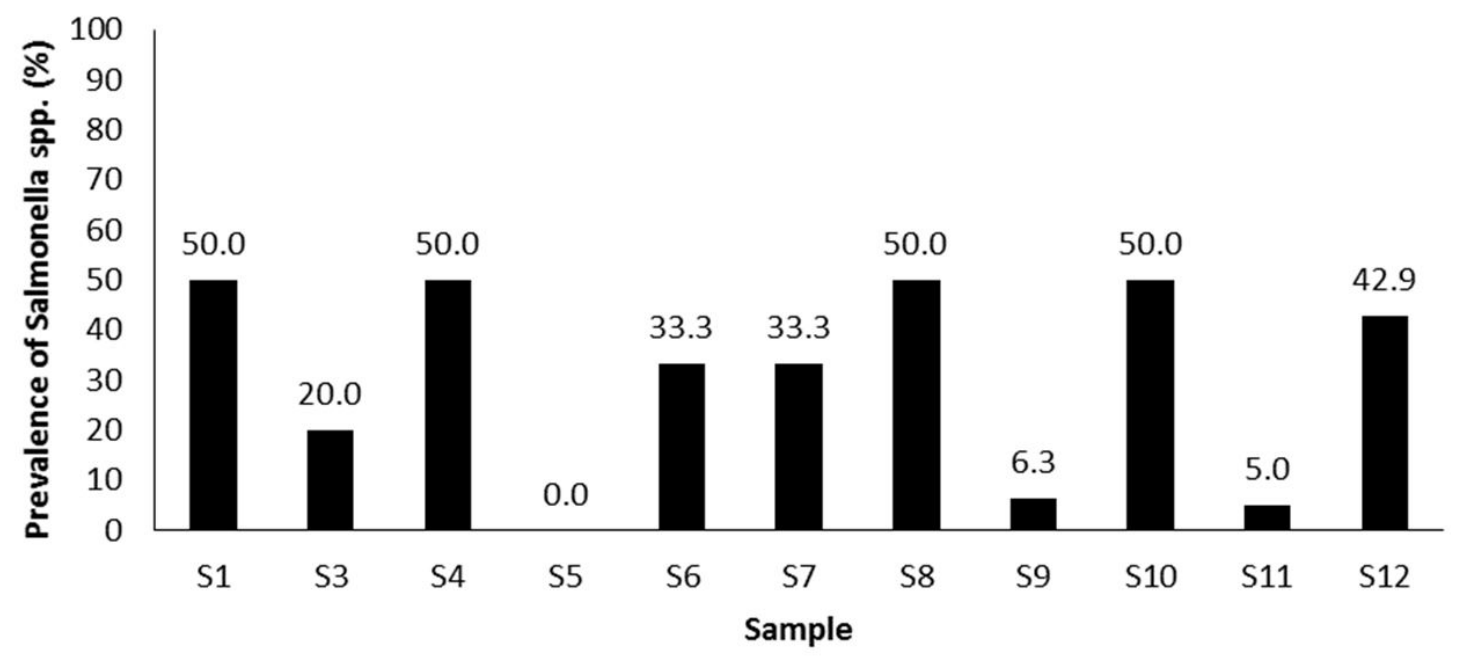

Note:

$\mathrm{S} 1=$ Raw chicken meat

S8 $=$ Marinated chicken meat

S3 = Ground water

S4 = Refilled drinking water

S9 $=$ Pre-cooked chicken meat

S5 = Processed seasoning

$\mathrm{S} 10=$ Stored pre-cooked chicken meat

S6 = Homemade seasoning

S7 $=$ Mortar

$\mathrm{S} 11=$ Fried chicken

S12 = Food handler's hand

Figure 2. Prevalence of Salmonella spp. from different sources throughout the fried chicken processing chain.

Six Salmonella serovars were found as presented in Table 3. Five Salmonella serovars were found on raw chicken meat and two serovars on pre-cooked chicken, while one serovar was found in both samples. In addition, one serovar was found in refilled drinking water as well as in pre-cooked chicken and raw chicken meat. Almost all isolates were resistant to at least one antibiotic, except $S$. Bergen which was susceptible to all antibiotics (Table 4). This study also found that Salmonella Typhimurium from raw chicken meat showed resistance to both nalidixic acid and tetracycline. In addition, all isolates were susceptible to trimethoprim-sulfamethoxazole and ampicillin.

\section{Discussion}

Raw chicken meat was the predominant source of Salmonella spp. contamination in the finished product. Ground water, refilled drinking water, homemade seasoning, cooking utensils (mortars), and food handler's hands were also confirmed as contributors to Salmonella spp. contamination 
Table 1. Positive results of Salmonella spp. in fried chicken processing chain.

\begin{tabular}{ccccc}
\hline \multirow{2}{*}{ No } & Sample & Sample number (n) & Sample number (n) & Positive results \\
\cline { 3 - 5 } & Raw chicken meat & 18 & 9 & $1.2-55.6$ \\
2 & Marinated raw chicken meat & 2 & 1 & 920.0 \\
3 & Pre-cooked chicken meat & 16 & 1 & 0.4 \\
4 & Stored pre-cooked chicken meat & 4 & 2 & 0.5 \\
5 & Fried chicken & 20 & 1 & 0.3 \\
\hline
\end{tabular}

Table 2. Number of Salmonella spp. in the cooking environment of the fried chicken processing chain.

\begin{tabular}{|c|c|c|c|c|c|}
\hline \multirow{2}{*}{ No } & \multirow{2}{*}{ Sample } & \multirow{2}{*}{ Sample number (n) } & \multicolumn{3}{|c|}{ Positive results } \\
\hline & & & Sample number (n) & Unit & MPN value \\
\hline 1 & Ground water & 10 & 2 & $\mathrm{MPN} / \mathrm{mL}$ & 67.0 \\
\hline 2 & Refilled drinking water & 4 & 2 & $\mathrm{MPN} / \mathrm{mL}$ & 0.3-2.0 \\
\hline 3 & Homemade seasoning & 3 & 1 & $\mathrm{MPN} / \mathrm{g}$ & 2.8 \\
\hline 4 & Mortar & 3 & 1 & MPN/utensil & 6.1 \\
\hline 5 & Food handler's hand & 7 & 3 & MPN/hand & $6.1-121.5$ \\
\hline
\end{tabular}

Table 3. Salmonella serovars on selected pathways of fried chicken preparation and cooking.

\begin{tabular}{cccc}
\hline Isolates & Sources & Serovar & ${ }^{*}$ Conformity \\
\hline R11CH & Raw chicken meat & Salmonella enterica strain FORC_030 & 99 \\
R21CH & Raw chicken meat & Salmonella enterica subsp. enterica serovar Bergen str. ST350 \\
R61BH & Raw chicken meat & Salmonella enterica subsp. enterica serovar Enteritidis strain FORC_052 & 99 \\
R72AMH & Raw chicken meat & Salmonella enterica subsp. enterica serovar Enteritidis strain GD1011 & 99 \\
R81BH & Raw chicken meat & Salmonella enterica subsp. enterica serovar Typhi strain 541 & 99 \\
R32AH & Pre-cooked chicken meat & Salmonella enterica subsp. enterica serovar Typhi strain 3N4 & 99 \\
R51BH & Stored pre-cooked chicken meat & Salmonella enterica subsp. enterica serovar Enteritidis strain FORC_052 & 99 \\
R42AH & Refilled drinking water & Salmonella enterica subsp. enterica serovar Enteritidis strain FORC_052 & 99 \\
\hline
\end{tabular}

*the conformity level was based on sequencing using $907 \mathrm{R}$ primers.

Table 4. Resistance of Salmonella serovars from various sources to antibiotics.

\begin{tabular}{|c|c|c|c|c|c|c|c|}
\hline Isolate & Serovar & Contamination sources & $\begin{array}{l}\text { Trimethoprim- } \\
\text { sulfame } \\
\text { thoxazole }\end{array}$ & Streptomycin & Ampicillin & $\begin{array}{l}\text { Nalidixic } \\
\text { acid }\end{array}$ & Tetracycline \\
\hline $\mathrm{R} 11 \mathrm{CH}$ & $\begin{array}{l}\text { S. Typhimurium strain } \\
\text { FORC_030 }\end{array}$ & Raw chicken meat & S & I & $S$ & $\mathrm{R}$ & $\mathrm{R}$ \\
\hline $\mathrm{R} 21 \mathrm{CH}$ & S. Bergen str. ST350 & Raw chicken meat & S & S & S & S & S \\
\hline $\mathrm{R} 61 \mathrm{BH}$ & $\begin{array}{l}\text { S. Enteritidis strain } \\
\text { FORC_052 }\end{array}$ & Raw chicken meat & S & I & $S$ & $\mathrm{R}$ & $S$ \\
\hline R72AMH & $\begin{array}{l}\text { S. Enteritidis strain } \\
\text { GD1011 }\end{array}$ & Raw chicken meat & $S$ & I & $S$ & $\mathrm{R}$ & $S$ \\
\hline $\mathrm{R} 81 \mathrm{BH}$ & S. Typhi strain 541 & Raw chicken meat & S & $\mathrm{R}$ & S & S & S \\
\hline $\mathrm{R} 32 \mathrm{AH}$ & S. Typhi strain 3N4 & Pre-cooked chicken meat & S & I & S & S & S \\
\hline $\mathrm{R} 51 \mathrm{BH}$ & $\begin{array}{l}\text { S. Enteritidis strain } \\
\text { FORC_052 }\end{array}$ & $\begin{array}{l}\text { Stored pre-cooked } \\
\text { chicken meat }\end{array}$ & $S$ & I & $S$ & $S$ & $S$ \\
\hline $\mathrm{R} 42 \mathrm{AH}$ & $\begin{array}{l}\text { S. Enteritidis strain } \\
\text { FORC_052 }\end{array}$ & Refilled drinking water & S & I & S & $\mathrm{R}$ & S \\
\hline
\end{tabular}

Note: $\mathrm{S}=$ Susceptible, $\mathrm{I}=$ Intermediate, $\mathrm{R}=$ Resistant.

in the finished product. The fact that Salmonella spp. was also found in pre-cooked chicken meat and fried chicken indicated inadequate heat processing during cooking or recontamination after the heating process.

Salmonella spp. contamination in raw chicken meat found in this study (9 of 18 samples, 50\%) supports a previous study indicating that poultry was one of the major reservoirs of
Salmonella spp. (Levin, 2009). Salmonella was also detected in one of three samples of homemade seasoning (Figure 2). The traditional mortar which was used for seasoning preparation likely contributed to the contamination, since Salmonella spp. was also found in one of the three mortars sampled. As a traditional mortar is usually made from stone, if it was not washed properly, it can retain Salmonella spp. originating from, for example, water 
used for cleaning. Another study showed that Salmonella spp. was found in cutlery that was washed using tap water in $24.49 \%$ of restaurants in Banda Aceh (Marissa \& Arifin, 2014).

After pre-cooking, the prevalence and number of Salmonella spp. were reduced. However, Salmonella spp. was still found in one of sixteen samples $(0.4 \mathrm{MPN} / \mathrm{g})$. Cooking at an internal meat temperature of $65^{\circ} \mathrm{C}$ for 6 min can reduce Salmonella spp. by more than $7 \log _{10}$ (Food Standard Australia New Zealand, 2017). During storage, the number of Salmonella spp. slightly increased, probably due to the ability of Salmonella spp. to grow at room temperature. Salmonella spp. is reported to have the ability to grow in chicken breast meat (skinless) stored at $13{ }^{\circ} \mathrm{C}$ and $21{ }^{\circ} \mathrm{C}$ for $3 \mathrm{~h}$, as well at $30{ }^{\circ} \mathrm{C}$ for $4 \mathrm{~h}$ (Ingham et al., 2007).

This study revealed that there are many factors such as water, seasoning, cooking equipment and food handler's hands enabling Salmonella spp. to contaminate chicken meat during the preparation and cooking. Ground water may be one of the sources of Salmonella spp. contamination, with a prevalence of $20.0 \%$ (2 of 10 samples) (Figure 2). A study of an outbreak of gastroenteritis in Croatia found that Salmonella enterica subsp. enterica serovar Enteritidis was present in well water used by patients (Kovačić et al., 2017). In addition, refilled drinking water used by households was also probable as a source of contamination with a prevalence of $50.0 \%$ (2 of 4 samples) (Figure 2). A recent study showed that refilled drinking water in Jember University Indonesia was detected containing Salmonella sp. (Nurhayati et al., 2018). In addition, during the preparation of chicken meat, $60 \%$ of housewives did not use separate utensils for cooked and uncooked food (Rosniawati et al., 2018). Salmonella spp. has the ability to form a biofilm on the surface of cooking equipment, leading to bacterial contamination on the product prepared (Myszka \& Czaczyk, 2011). Therefore, proper washing practices of cooking wares are required. This study showed that unwashed food handler's hands and the use of well water for hand washing are potentially becoming the source of Salmonella spp. contamination (Figure 2). A previous survey showed that $20 \%$ of housewives were not aware of the importance of washing their hands before preparing fried chicken (Rosniawati et al., 2018). Hand sanitation is one of the important factors associated with Salmonella spp. contamination (Trimoulinard et al., 2017). In general, hand washing enables microorganisms on hands to be eliminated. Hand washing with soap for 20 seconds can reduce E. aerogenes artificially added to hands by a total of $1.7 \pm 0.8 \log \mathrm{CFU} / \mathrm{mL}$. This treatment was more effective in comparison to hand washing without soap, with a total reduction of $1.0 \pm 0.4 \log \mathrm{CFU} / \mathrm{mL}$ (Jensen et al., 2015).

This study revealed that although Salmonella spp. was not found in prepared seasoning from the market, housewives should be aware of the presence of other microbial hazards. Other study showed that ground chili in a traditional market in Bogor contained total microorganism content of $7.9 \times 10^{4}-1.9 \times 10^{7} \mathrm{CFU} / \mathrm{g}$ (Rosaria \& Rahayu, 2008).

Among 23 samples which were found positive for Salmonella using PCR, only 8 samples or 8 isolates had thick DNA bands. These samples were then sequenced. The sequencing results using 907R primer showed that Salmonella spp. isolate of raw chicken meat demonstrated $99 \%$ conformity to the sequence genome of four different serovars of Salmonella enterica including $S$. Bergen, S. Typhimurium, S. Enteritidis and S. Typhi. Strain FORC_030 has a characteristic relationship with Salmonella enterica serovar Typhimurium (Lee et al., 2018). Various Salmonella serovars have been found on raw chicken meat. In Colombia, Salmonella serovar on raw chicken carcasses were identified including Salmonella Paratyphi B dt +, Heidelberg, Enteritidis, Typhimurium and Anatum (Donado-Godoy et al., 2014). In Vietnam, however, Salmonella serovar on chicken carcasses from two cities and two provinces including Albany, Agona dan Dabou were identified (Ta et al., 2012).

Salmonella serovar on chicken processed chicken meat has $99 \%$ conformity to the sequence genome of two different serovars of Salmonella enterica including serovar S. Typhi and serovar S. Enteritidis. Salmonella spp. isolates on refilled drinking water meanwhile have $99 \%$ conformity to the sequence genome of $S$. Enteritidis. These serovars were also found in groundwater samples of gastroenteritis outbreak that occurred in Sibenik, Croatia (Kovačić et al., 2017).

This study showed that Salmonella serovars (S. Typhimurium and $S$. Enteritidis) from raw chicken meat were resistant to nalidixic acid, streptomycin, and tetracycline (Table 4). This result was in accordance with previous studies. Salmonella spp. isolates derived from chicken production chains in slaughterhouses and retail markets exhibited high resistance to tetracycline (77\%) and nalidixic acid (41\%) (Li et al., 2013). Another study reported that Salmonella isolates derived from broiler chicken (44.4\%) (Aprillian et al., 2015) and poultry origin (77.8\%) (Myšková \& Karpíšková, 2017) also showed resistance to nalidixic acid. This study revealed that all Salmonella serovars derived from raw chicken meat, pre-cooked chicken and refilled drinking water (S. Typhimurium, S. Bergen, $S$. Enteritidis, and S. Typhi) were considered "susceptible" to trimethoprim-sulfamethoxazole (100.0\%), ampicillin (100.0\%) and tetracycline (87.5\%) (Table 4), which contrasts with previous studies. Salmonella isolates from chicken production chains (slaughterhouses and retail markets) displayed the greatest resistance to sulfamethoxazole/ trimethoprim (43\%) (Li et al., 2013), while the other study found that Salmonella isolates from poultry and environmental samples were resistant to ampicillin (89.5\%) (Chuah et al., 2018). This study showed that $S$. Typhimurium strain FORC_030 can be classified as multidrug-resistant.

\section{Conclusions}

The presence of Salmonella on raw chicken meat indicated that initial contamination plays an important role as one of the main sources of Salmonella in the preparation and cooking of fried chicken. Other factors, i.e. water, seasoning, cooking ware, and food handler's hands, were found to also contribute considerably to the presence of Salmonella in fried chicken. Since Salmonella serovars found on the preparation and cooking of fried chicken showed resistance to a particular antibiotic, the consumer should be aware that they should apply good handling and cooking practices during the preparation of fried chicken. 


\section{Acknowledgements}

The author would like to thank the Food and Drug Authority, the Republic of Indonesia for financial support in conducting this research.

\section{References}

Aprillian, R., Rahardjo, D., \& Koesdarto, S. (2015). Evaluation of Salmonella sp contamination and its antibiotics resistance patterns isolated from broiler meat sold at wet market in center of Surabaya. Indonesian Journal of Tropical and Infectious Disease, 5(6), 143-146. http://dx.doi.org/10.20473/ijtid.v5i6.440.

Chuah, L. O., Shamila Syuhada, A. K., Mohamad Suhaimi, I., Farah Hanim, T., \& Rusul, G. (2018). Genetic relatedness, antimicrobial resistance and biofilm formation of Salmonella isolated from naturally contaminated poultry and their processing environment in northern Malaysia. Food Research International, 105, 743-751. http://dx.doi.org/10.1016/j.foodres.2017.11.066. PMid:29433269.

Clinical \& Laboratory Standards Institute - CLSI. (2013). M02-A11 CLSI : performance standards for antimicrobial disk susceptibility tests; approved standard. Wayne: CLSI.

Donado-Godoy, P., Clavijo, V., Leon, M., Arevalo, A., Castellanos, R., Bernal, J., Tafur, M. A., Ovalle, M. V., Alali, W. Q., Hume, M., Romero-Zuñiga, J. J., Walls, I., \& Doyle, M. P. (2014). Counts, serovars, and antimicrobial resistance phenotypes of Salmonella on raw chicken meat at retail in Colombia. Journal of Food Protection, 77(2), 227-235. http://dx.doi.org/10.4315/0362-028X.JFP-13-276. PMid:24490916.

Food Standard Australia New Zealand. (2017). Imported food risk statement ready-to-eat cooked chicken meat and Salmonella spp. Retrieved from https://www.foodstandards.gov.au

Indonesia National Agency of Drug and Food Control. (2016). Salmonella quantitative analysis on fried chicken using most probable number (MPN) methods and PCR confirmation. Jakarta: BPOM RI.

Ingham, S. C., Fanslau, M. A., Burnham, G. M., Ingham, B. H., Norback, J. P., \& Schaffner, D. W. (2007). Predicting pathogen growth during short-term temperature abuse of raw pork, beef, and poultry products: use of an isothermal-based predictive tool. Journal of Food Protection, 70(6), 1446-1456. http://dx.doi.org/10.4315/0362-028X-70.6.1446. PMid:17612076.

Jensen, D. A., Danyluk, M. D., Harris, L. J., \& Schaffner, D. W. (2015). Quantifying the effect of hand wash duration, soap use, ground beef debris, and drying methods on the removal of Enterobacter aerogenes on hands. Journal of Food Protection, 78(4), 685-690. http://dx.doi.org/10.4315/0362-028X.JFP-14-245. PMid:25836392.

Kovačić, A., Huljev, Ž., \& Sušić, E. (2017). Ground water as the source of an outbreak of Salmonella Enteritidis. Journal of Epidemiology and Global Health, 7(3), 181-184. http://dx.doi.org/10.1016/j. jegh.2017.05.001. PMid:28756827.

Lee, H., Kim, S. I., Park, S., Nam, E., \& Yoon, H. (2018). Understanding comprehensive transcriptional response of Salmonella enterica spp. in contact with cabbage and napa cabbage. Journal of Microbiology and Biotechnology, 28(11), 1896-1907. http://dx.doi.org/10.4014/ jmb.1806.06018. PMid:30270599.

Levin, R. E. (2009). Rapid detection and characterization of foodborne pathogens by molecular techniques. Boca Raton: CRC Press. http:// dx.doi.org/10.1201/9781420092431.

Li, R., Lai, J., Wang, Y., Liu, S., Li, Y., Liu, K., \& Wu, C. (2013). Prevalence and characterization of Salmonella species isolated from pigs, ducks and chickens in Sichuan Province, China. International Journal of Food Microbiology, 163(1), 14-18. http://dx.doi.org/10.1016/j. ijfoodmicro.2013.01.020. PMid:23474653.

Marissa, N., \& Arifin, A. Y. (2014). Higienitas peralatan makan berdasarkan keberadaan Salmonella Sp. Di Warung Makan Kota Banda Aceh. Sel Jurnal Penelitian Kesehatan, 1(1), 9-16.

Myšková, P., \& Karpíšková, R. (2017). Prevalence and characteristics of Salmonella in retail poultry and pork meat in the Czech Republic during 2013-2014. Czech Journal of Food Sciences, 35(2), 106-112. http://dx.doi.org/10.17221/260/2016-CJFS.

Myszka, K., \& Czaczyk, K. (2011). Bacterial biofilms on food contact surfaces-a review. Polish Journal of Food and Nutrition Sciences, 61(3), 173-180. http://dx.doi.org/10.2478/v10222-011-0018-4.

National Center for Biotechnology Information - NCBI. (2017). Bethesda: NBCI. Retrieved from http://blast.ncbi.nlm.nih.gov

Nurhayati, N., Sari, P., Fauziah, R. R., \& Belgis, M. (2018). Detection of bacterial contamination on refill drinking water: case study in Jember University campus. In Proceeding on National Seminar of Food Science. Bogor: Food Science Study Program, Department of Food Science and Technology, IPB University.

Rosaria, \& Rahayu, W. P. (2008). Study on safety and shelflife of red chili paste. Jurnal Teknologi dan Industri Pangan, 19(1), 8.

Rosniawati, T., Rahayu, W. P., Kusumaningrum, H. D., Indrotristanto, N., \& Abdy, I. (2018). Perception and behavior housewife in fried chicken processing. In Proceeding on National Seminar of Food Science. Bogor: Food Science Study Program, Department of Food Science and Technology, IPB University.

Syarifah, I., \& Novarieta, E. (2015). Detection of Salmonella sp. on beef and chicken meat. In Proceeding of National Seminar on Animal and Veterinary Technology. Bogor: Indonesian Center for Animal Research and Development.

Sylviana \& Kusumaningrum, H. D. (2008). The prevalence of Salmonella on chicken carcass slices from traditional and modern market in Bogor and its control efforts. In Proceeding of National Seminar and PATPI Congress. Palembang: The Indonesian Association of Food Technologists.

Ta, Y. T., Nguyen, T. T., To, P. B., Pham, X., Le, H. T., Alali, W. Q., Walls, I., Lo Fo Wong, D. M., \& Doyle, M. P. (2012). Prevalence of Salmonella on chicken carcasses from retail markets in Vietnam. Journal of Food Protection, 75(10), 1851-1854. http://dx.doi.org/10.4315/0362-028X. JFP-12-130. PMid:23043836.

Trimoulinard, A., Beral, M., Henry, I., Atiana, L., Porphyre, V., Tessier, C., Leclercq, A., \& Cardinale, E. (2017). Contamination by Salmonella spp., Campylobacter spp. and Listeria spp. of most popular chickenand pork-sausages sold in Reunion Island. International Journal of Food Microbiology, 250, 68-74. http://dx.doi.org/10.1016/j. ijfoodmicro.2017.03.017. PMid:28371717. 